\title{
関東・東海地域の地殻応力
}

\author{
国立防災科学技術センター 塚 原 弘昭・池田隆司
}

(昭和 58 年 8 月 2 日受理)

\section{State of Stress in the Kanto-Tokai Area}

\author{
Hiroaki Tsukahara and Ryuji IKeda \\ National Research Center for Disaster Prevention, Sakuramura, Ibaraki
}

(Received August 2, 1983)

\begin{abstract}
A map of the maximum compressive stress direction has been made for the Kanto-Tokai area from the data of in-situ stress measurements, focal mechanisms of earthquakes, and geological evidences. Data compiled, which amounts to 77 points, includes the following: 10 points of hydraulic fracturing stress measurments, 3 points of overcoring stress measurments, 7 points of Quaternary dike trends, 9 points of Quaternary monogenetic volcano alignments (including flank volcanoes), 41 points of active fault movements and 7 points of focal mechanism solutions of shallow earthquakes (depth $<20 \mathrm{~km}, M>6.5$ ). The data points which lie close to one another give a similar stress condition: the stress orientation and stress state classified by fault type such as normal, reverse, and strike-slip faults. We have divided the Kanto-Tokai area into seven provinces on the basis of the data compiled after consideration of the plate interation among the Eurasian, the Philippine Sea and the Pacific plates. Stress condition within each province appears almost uniform. The seven stress provinces and their averaged azimuths for the maximum horizontal compressive stresses $S_{H \text { max }}$ are as follows: southern part of Nagano Prefecture (NA), N85 ${ }^{\circ} \mathrm{W}$; northern part of the Kanto district (KA), $\mathrm{N} 80^{\circ} \mathrm{W}$; Shizuoka district (SZ), $\mathrm{N} 40^{\circ} \mathrm{W}$; Nishiizu district (NI), $\mathrm{N} 10^{\circ} \mathrm{E}$; Higashiizu district $(\mathrm{HI}), \mathrm{N} 40^{\circ} \mathrm{W}$; Tanzawa district (TN), N-S; and the Miura-central Boso district $(\mathrm{MB}), \mathrm{N} 35^{\circ} \mathrm{W}$. The azimuths of $S_{\boldsymbol{H} \max }$ in stress provinces $\mathrm{NA}$ and $\mathrm{KA}$ are both nearly $\mathrm{E}-\mathrm{W}$, which is attributed to the westward relative movement of the Pacific plate against the Eurasian plate. The azimuths of $\mathrm{N} 35^{\circ}-40^{\circ} \mathrm{W}$ in provinces SZ, HI and $\mathrm{MB}$ are considered to be due to the northwestward movement of the Philippine Sea plate relative to the Eurasian plate. The cause for the individual orientation of $S_{H \max }$ as $\mathrm{N} 10^{\circ} \mathrm{E}$ in province $\mathrm{NI}$ is interpreted as being a result of the downward bending of the Philippine Sea plate at the Suruga trough. That is, the extension perpendicular to the bending axis is effected on the surface by the downward bending, which result in the parallel orientation of the $S_{H \max }$ to the trough. In the case of province $\mathrm{TN}$, the stress orientation in the province is not interpreted in terms of downward bending because the subduction has not been expected in the province. This is one of the subjects for future study. In stress province $M B$, the direction of $S_{H \max }$ agrees well with the horizontal maximum compressive strain accumulated during the period from 1882/1902 to 1973/80. However, the direction does not agree well with that of the strain accumulated during the period from 1924/25 to $1973 / 80$. The difference is one reason for low seismicity in the upper crust in province $\mathrm{MB}$, since current crustal movement does not work efficiently to increase the in-situ differential stress. The difference may be attributed to the long-term after-effect of the 1923 Kanto earthquake.
\end{abstract}

昭和 57 年 10 月 7 日発表 


\section{$\S 1$. 序}

この地域はプレートテクトニクスによると三つのプレート：太平洋プレート・ユーラシアプ レート・フィリピン海プレートの会合部であり, これらプレートの相互作用を反映してこの地 域の地殼の応力状態は大変複雑であろらと推測される.この三つのプレートの相互の関係につ いては，杉村 (1972) がフィリピン海プレートとユーラシアプレートの境界を, 駿河トラフ・ 伊豆北方・相模トラフを結ぶ地域に同定して以来，多数の研究が報告されてきた．杉村はフィ リピン海プレートとニーラシアプレートとの関係を，伊豆半島北方では主として衝突であると 指摘した．石橋 (1976)・ISHIBASHI (1981) はユーラシアプレートの下へフィリピン海プレート が，駿河トラフで歴史的・継続的にもぐり込んでいることを強調した。石橋の主張以後, 駿河 トラフでのもぐり込みによる地震の発生が危惧され, 地震予知研究との関連で大変多くの研究 者がこの地域のテクトニクスに注目し, 地震・地殼変動に関するデータも急速に蓄積した。そ の中で笠原 $(1980,81)$ は微小地震の震源分布および地震発震機構から, 相模トラフにおいて は, フィリピン海プレートがここから北方へニーラシアプレートの下へもぐり込み，その北の 端はほぼ埼玉県北部・茨城県中部にむで達しており, 太平洋プレートはさらにその下に東から 西に向かって沈み込んでいると主張した。

このよらなプレートの相互運動が次第に明らかにされてくる中で, 日本列島の地殼応力につ いて松田・他 (1978) は, 日本列島の地表近くの応力状態を応力軌跡図としてまとめて表現し た.これは，地表近くで測定あるいは推定された最大水平圧縮応力 $S_{H \max }$ の方位を，なめら かな曲線で結び広い地域の応力状態を概観しょうとしたものである。データは当時をでに得ら れていた応力解放法による応力測定結果・第四紀火山の構造・活断層の変位方向・浅い地震の 発震機構から推定された応力方位を採用している.この応力軌跡図によると, 関東・伊豆地方 では応力軌跡が大きく曲げられ，応力状態の複雑さが反映されている．しかし，まだデータは 少なく，この応力軌跡図は確定したものではなかった.

さらに, 中村 $(1979,80)$ はデータの多い伊豆半島および伊豆周辺の $S_{H \max }$ 方位の分布を詳 しく調查し，駿河トラフと相模トラフに挾まれた東西 $100 \mathrm{~km}$ に満たない狭い範囲で， $S_{H \text { max }}$ 方位が両トラフの付近ではそれぞれのトラフに平行になるよらに，系統的に変化しているよう に見えることに注目した．中村はフィリピン海プレートがこの地域ではトラフ付近で下方へ曲 がりながらもぐり込んでいるために，この曲がり現象が上部地殼の $S_{\text {H max }}$ 方位を支配してい ると主張した。

その後データはさらに蓄積され, 特に, 水圧破壊法および応力解放法による直接測定データ [塚原・他 $(1980,81,83 \mathrm{a}, \mathrm{b}$; 池田・高橋 $(1981,83)$; 小出 $(1980)$; 小出 - 他 $(1981,82)$ ] の 增加, および活断層研究会 (1980) による日本列島内の個々の活断層の活動度・確実度の定量 的評価の公表はこの間の大きな進展であった。この報告では, 応力方位に関するすべてのデー タををとめ, 関東・東海地域の応力状態を推定してみる. 三つのプレートの相互運動との関連 についても議論したい.

\section{§2. 最大水平玫宿応力 $\boldsymbol{S}_{H \text { max }}$ 方位データ}

実測データ・発震機構・第四紀の地質現象から算出あるいは推定される $S_{H \max }$ 方位のデー タを集め吟味した。それぞれの推定法により得られたデータの特徵・精度について以下に述べ 
る.個々の数值抢よび引用文献は付録を参照されたい。

\section{1. 実測データ}

a) 水圧破壊法

水圧破壊法による地壳応力の測定は以下の手順で行なわれる．掘削した孔井の一部区間の上 下を栓で密封し，水圧をかけて孔壁に割れ目を作る．理論上この割れ目は鉛直で $S_{H \text { max }}$ 方位 に平行に出現する [HUBBERT and WILLIS (1957)]. 破壊方位を超音波テレビュア，または型 取りパッカーで検出し $S_{H \text { max }}$ の方位を知る. 水平面内の主応力值 $S_{H \text { max }} \cdot S_{H \text { min }}$ は水圧変化記 録から算出される $\left(S_{H \text { min }}\right.$ は最小水平圧縮応力). 詳しくは塚原 ・他 $(1978,80)$ を参照された い. 超音波テレビュアは超音波の反射強度を全孔壁にわたって調査できる装置である．破壊が 孔壁に現われていれば，そこからの反射強度が弱くなりこれを検出できる. 型取りパッカーは, 水圧破壊実施か所で可塑性ゴムを貼りつけたゴム製のパッカーを水圧で膨張させ，孔壁の型を 取ることにより割れ目の方位を検出するものである.

今回採用しているデータは, 深さ $450 \mathrm{~m}$ および $600 \mathrm{~m}$ の測定孔中で約 $2 \mathrm{~m}$ 間を密封して 水圧破壊して測定したものである．種々の深度で何力所かで測定を繰り返している．測定孔を 構成する岩石の破壊強度に異方性があると䛊差は大きくなる. 同じ測定孔中で深度を変えて測 定された破壊方位のばらつきは \pm 20 度程度である [塚原・他 (1983a)].

b) 応力解放法

応力解放法には種々の手法があるが，この地域で実施されデータが得られているのは孔径変 化法である. 固い岩盤が地表に露出している地域に深さ $20 \mathrm{~m}$ 程度の湘定孔を掘削し, その中 で応力解放前後の孔径を測定し岩盤の弾性定数を考慮に入れて水平応力を算出する. 得られた 応力值から水平面内での主応力方位を算出する．差応力が大きい場合には主応力方位の誤差は 少ないが，小さい場合には誤差が大きい. 数 $\mathrm{km}$ の範囲で複数の測定孔から得られた丹沢山 地での結果によると, 主応力方位のばらつきは \pm 10 度程度である [小出 (1980)].

\section{2. 火山の構造からの推定}

a) 岩脈方位

火山の構造と応力との関係について言及されたのは比較的古く, 1957 年に ODE は Spanish Peaks の多数の岩脈の方位分布が応域応力場に影響されていると指摘している [ODÉ (1957)]. 中村 $(1969,75) \cdot$ NAKAMURA (1977)·NAKAMURA et al. (1977) は，マグマが岩盤を割って貫 入・噴出するとき，それが鉛直の場合は水圧破壊と同じ原理で岩脈が $S_{H \text { max }}$ の方位に平行に 貫入するはずである，と明確に述べ，野外の観察事実にも基づいて“岩脈法”を確立した。

岩脈が地表に現われるには，かなりの侵食の進行が必要である。そのために, 新しい時代の 岩脈が地表に現われている露頭は比較的少ない。ここでは, 第四紀以降 (<2 Ma) の岩脈方位 の測定值で年代の判明しているものだけを採用したので更に数は少ない.しかし岩脈の年代測 定が進めばデータはもう少し増加するものと思われる.

同じ火山活動によって発生したと推定される多数の岩脈がある場合には，それらの測定され た方位の平均值を採用した，測定值は \pm 10 度程度のばらつきである.

b) 単成火山群 (側火口群を含む) の配列

中村 $(1969,75) \cdot$ NAKAMURA (1977)·NAKAMURA et al. (1977) は, 側火口群を含む単成火 山群は岩脈状のマグマの一部から派生したものであると指摘し，それらの配列方位は岩脈方位 
と同じく地殼応力を反映していると主張した，すなわち，これらの配列方位が $S_{H \text { max }}$ 方位を 示していることになる．岩脈と比べると，地表で若い時代のものが多く観察できる．データと しては第四紀火山活動を選んだが，結果的にはこの地域では $0.3 \mathrm{Ma} よ り$ 新しいものばかり になった．火山の分布が帯状であり，卓越した配列方位を選ぶのに任意性があるので，方位は \pm 20 度程度誤差があると考えた方が良い。

\section{3. 断層の動きからの推定}

a) 活断層

活断層の動きから主応力方位を推定し，その地域分布を議論した例はすでにいくつか報告が ある[例之ば，松田 (1967)]. 最近, 活断層研究会 (1980) により, 日本列島内の活断層の調查 と個々の断層の確実度・活動度についてのランク付けがなされたこれれよって任意の地域内 にある活断層を統一した基準でふるい分けて，一定以上のランクのものを拾い出して議論する ことができるようになった。これを用いて，関東・東海地域にある活断層を取捨選択し，主応 力方位の推定に用いた．確実度 II 以上* で活動度 B 級以上**を選択した [*I：活断層であ ることが確実なもの，II：活断層と推定されるもの;**平均変位速度 $\geqq 0.1 \mathrm{~m} / 1000$ 年, 活断 層研究会 (1980) による].

活断層から応力方位を推定する場合に，断層の三次元的動きを評価することのむずかしさの ほかに，以下のような岩石の物性に依存する不確定な要素があり，推定される応力方位には必 然的にある䛊差が含まれる．(1) 活断層が周囲の岩石と比べて著しく強度が弱い場合には, 活 断層の動きから導き出される主応力方位は, 理論的には最大 \pm 45 度の許容範囲がある（活断 層面が摩擦係数ゼ口の場合)。共役の断層がある場合はこの限りではないが，共役の断層が同 時に動くことは少ない（2）破壊角（最大圧縮軸と破壊面とのなす角）は岩石の物性・応力状 態により異なるため，理想的に均質な強度の岩石の破壊においてさえも，破壊面から得られる 情報だけからは $S_{H \text { max }}$ の方位は一義的には決められない，

しかしながら，地款応力の主応力軸の一つが鉛直であり，したがって他の二つが水平面内に ある場合が多いので [例えば, MCGARR and GAY (1978)], 大部分の活断層は三次元的動きと しては単純な正断層・逆断層・横ずれ断層のどれかに分類しても良さそらである。また，断層 面上での摩擦も大きいので，上記 (1) の許容範囲は \pm 45 度より小さくなることが期待される. さらに，(2) に関しては地表に現われている断層の破壊角は平均的には 30 度程度であること が経験的に知られている [例えば，JAEGER and COOK (1976) p. 421].

以上を勘案して，この報告では $S_{\text {H } \max }$ の方位は，主要な動きが縱ずれである正断層および逆 断層の場合：その走向にそれぞれ平行および垂直; 主要な動きが横ずれの断層の場合：走向に 30 度，とした。

さらに，断層の動きからは応力方位に関する情報だけでなく，以下のように $S_{v}$ (鉛直応力)・ $S_{H \text { max }} \cdot S_{H \text { min }}$ の三つの応力の相対的大小関係が推定できる.

(i) 逆断層が生ずる応力状態

$$
S_{v}<S_{H \min }<S_{H \max }
$$

(ii) 正断層が生ずる応力状態

$S_{H \text { min }}<S_{H \text { max }}<S_{v}$

(iii）横ずれ断層が生ずる応力状態 


$$
S_{H \text { min }}<S_{v}<S_{H \max }
$$

なお，上記 (i)・(ii) の状態は，一方向からだけの水平営力で生じさせることが可能であるが [(i) の場合は圧縮力, (ii) の場合は引張力], (iii) は一方向からの水平圧縮力に加えて, 水平面 上でそれと直角の方向からの引張力が存在しなければならない．この点は，(iii) の応力状態が 支配している地域の地殼変動を考える場合大変重要である.

b) 発震機構

地震観測データから断層面解を得ることによって，地震を発生した断層面およびその動きを 知ることができる.この報告では, 深さ $20 \mathrm{~km}$ より浅い地震で, マグニチュード 6.5 より大 きいものを採用した，活断層と同様に，この断層の地震時の動きから， $S_{H \text { max }}$ 方位を求める. すなわち，最大圧縮力の方向は，断層面上のすべり方向と 30 度とし，水平面への投影を $S_{H \text { max }}$ 方位とする. また，活断層と同様に応力状態を断層の動きから 3 種類に分類することが できる。

\section{§ 3. $\boldsymbol{S}_{\text {H max }}$ 方位の分布と応力区}

関東・東海地域で測定された $S_{H \text { max }}$ の方位に関するデータを前節の基準に従って選択し， その方位を Fig. 1 に示す．測定された手法による違いをシンボルの違いで示す．水圧破壊法 による測定值は 10 個・応力解放法による測定値は 3 個・岩脈法によるもの 7 個・単成火山の

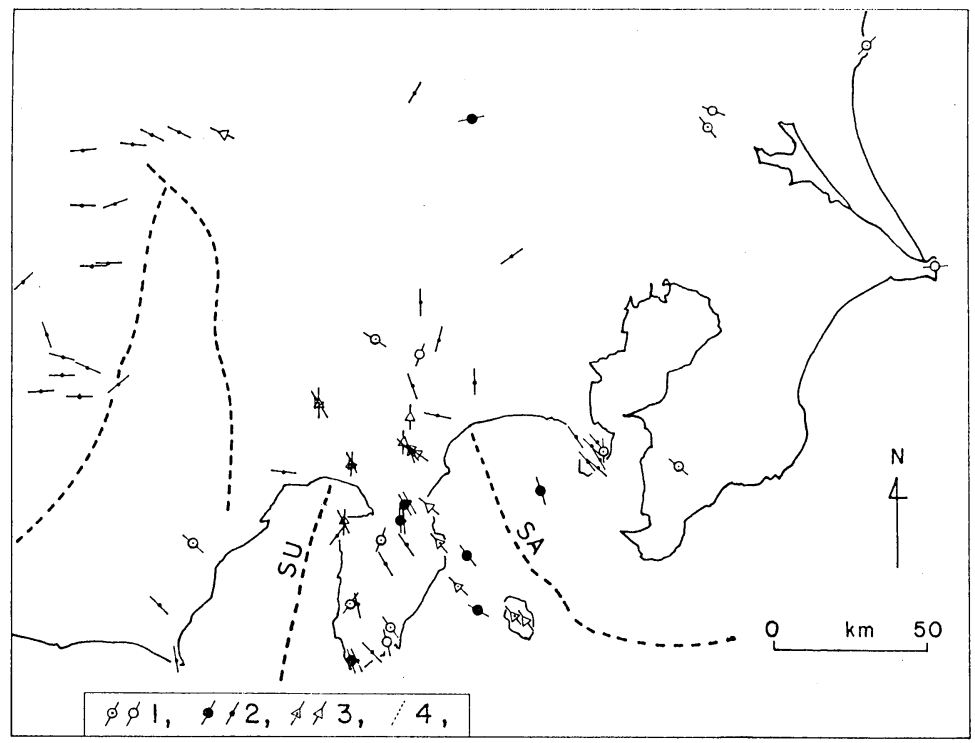

Fig. 1. Directions of the maximum horizontal compressive stresses of $S_{\text {Hax }}$. 1: Insitu stress measurements; hydraulic fracturing method (symbol with a dot) and overcoring method, 2: Fault movements; focal mechanisms of earthquakes (large black symbol) and active faults, 3: Volcano structures; monogenetic volcano alignments (including flank volcanoes; symbol with a dot) and dike trends, and 4: Major tectonic lines; SU: Suruga trough and SA: Sagami trough. For detailed descriptions of the data see tables in Appendix. 
配列によるもの 9 個・活断層からの推定 41 個・発震機構によるもの 7 個で合計 77 個のデー タが示されている。データのリストおよび出典は付録の表および図を参照されたい。

伊豆周辺にデータが集中しており, 関東地方特に平野部はデータが少ない. 隣り合った近く のデータは，測定法・年代の違いによらずお执むね同じ方位を示している点が注目される.

フィリピン海プレートが, 駿河・相模両トラフで, 関東・東海地域の下へ沈み込んでいると いうプレートモデルを考慮しつつ，応力の方位拈よび応力状態にしたがって区域分けしてみる. その結果を Fig. 2 に示す. 斜線の方位は個々の区域内の測定データから得られた $S_{H \max }$ 方位 の平均方位を示す，このような，一様な応力状態が支配している個々の区域を，ZOBACK and ZoBACK (1980) ・小林 (1980) にならって“応力区 (Stress Province)”と呼ぶことにする. Fig. 2 は, 関東・東海地域を, 長野県南部 $(\mathrm{NA}) \cdot$ 関東北部 $(\mathrm{KA}) \cdot$ 三浦一房総中部 $(\mathrm{MB}) \cdot$ 東伊豆 $(\mathrm{HI})$ ・西伊豆 $(\mathrm{NI})$ ・ 丹沢 $(\mathrm{TN})$ ・静岡 (SZ) の 7 個の応力区に分けたことになる.

個々の応力区の $S_{H \text { max }}$ 方位抢よび断層型で分類される応力状態は以下のようである.

(i) 長野県南部応力区一 $\mathrm{NA}$

$S_{H \text { max }}$ の平均方位は $\mathrm{N} 85^{\circ} \mathrm{W}$ であり, 応力状態は横ずれ断層型のものが大部分である.

(ii) 関東北部応力区一-KA

$S_{H \text { max }}$ の平均方位は $\mathrm{N} 80^{\circ} \mathrm{E}$ であり, 応力状態は逆断層型のものが多い.

(iii) 三浦一房総中部応力区- $\mathrm{MB}$

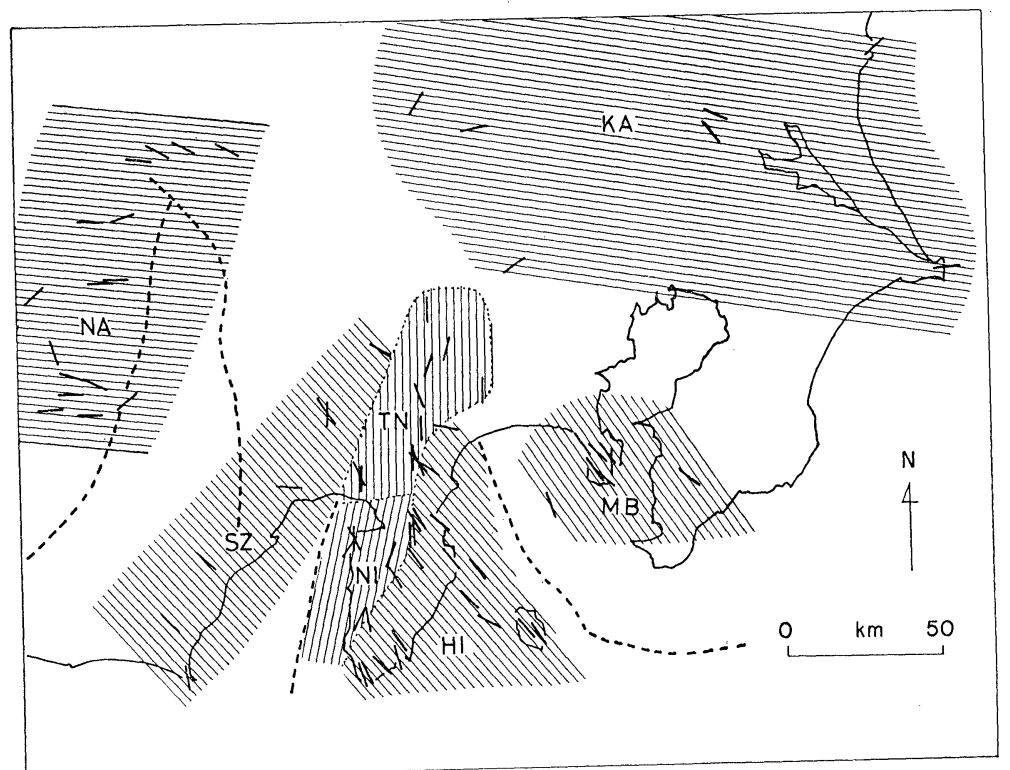

Fig. 2. $S_{H \text { max }}$ direction map: Stress province map. The azimuth of lines indicates the average direction of $S_{H \text { max }}$ in the stress province. NA: Southern part of Nagano Prefecture, $\mathrm{N} 85^{\circ} \mathrm{W} ; \mathrm{KA}$ : Northern part of the Kanto district, $\mathrm{N} 80^{\circ} \mathrm{W}$; $\mathrm{SZ}$ : Shizuoka district, $\mathrm{N} 40^{\circ} \mathrm{W}$; NI: Nishiizu district, $\mathrm{N} 10^{\circ} \mathrm{E} ; \mathrm{HI}$ : Higashiizu district, $\mathrm{N} 40^{\circ} \mathrm{W}$; TN: Tanzawa district $\mathrm{N}-\mathrm{S}$; and $\mathrm{MB}$ : the Miura-cental Boso district, $\mathrm{N} 35^{\circ} \mathrm{W}$. 
$S_{H \text { max }}$ の平均方位は $\mathrm{N} 35^{\circ} \mathrm{W}$ であり，応力状態は横ずれ断層型および逆断層型である. (iv) 丹沢応力区一 $\mathrm{TN}$

$S_{\text {Hmax }}$ の平均方位は $\mathrm{N}-\mathrm{S}$ であり，応力状態は横ずれ断層型および逆断層型である. (v) 東伊豆応力区一-HI

$S_{H \text { max }}$ の平均方位は $\mathrm{N} 40^{\circ} \mathrm{W}$ であり, 応力状態は横ずれ断層型である.

(vi) 西伊豆応力区一- $\mathrm{NI}$

$S_{H \text { max }}$ の平均方位は $\mathrm{N} 10^{\circ} \mathrm{E}$ であり，応力状態は正断層型および横ずれ断層型である.

(vii) 静岡応力区- $\mathrm{SZ}$

$S_{H \text { max }}$ の平均方位は $\mathrm{N} 40^{\circ} \mathrm{W}$ であり, 応力状態は逆断層型のものが多い.

応力区と応力区との境界がはっきりしているのは, 伊豆半島内の西伊豆 $(\mathrm{NI})$ と東伊豆 $(\mathrm{HI})$ の両応力区の境界, および伊豆半島北方の丹沢 (TN) と NI との境界である. 伊豆半島内の NI と HI との境界は, 中野・他 (1980) および小林 (1980) がすでに指摘しているように, 伊 豆半島中部を通る南北の “線”を境にして，応力方位が急激に変化する．小林の指摘後に水圧 破壞法によって測定された修善寺（付録の Fig. A-1 中の H4) および下田（同 H3）の結果 もこれを支持している.これら以外の応力区間の境界はデータの数が少なく, 応力方位が急激 な変化をしているのか次第に変化しているのか定かではない，データの比較的密な応力区と応 力区との間をらめることができず, 結果的に 7 個の応力区で分けられたモザイク状になってい るとも言える．データが蓄積されるにしたがって，隣り合う応力区が一つになるところも，お るいはでてくるであろら．しかしながら，かなりの拡がりを持った応力区が，同じ応力状態に 支配されていること, さらに応力区の境界では急激な応力方位の変化が見られる地域があるこ とは, 現存のデータだけからもはっきりしており，この結果は，応力を発生している原動力を 考える上で無視できない重要な事実である.

\section{$\S 4$. 議 論}

a) 長野県南部 (NA) ・ 関東北部 (KA) 応力区について

両応力区は良く似た $S_{\text {H max }}$ 方位を持っている. なめらかに一つに合体する可能性もあるが， 断層型で分けられる応力状態が異なる点とデータの空白域が大きいので別々の応力区にした.

両応力区とも西進してくる太平洋プレートの影響を強く受け，泀ぼ東一西の $S_{H \text { max }}$ 方位とな っていると解积される．但し KA に関しては笠原 $(1980,81)$ が主張するように, 関東平野の 数十 $\mathrm{km}$ 下に相模トラフから沈み込んできたフィリピン海プレートが存在するならば，応力 区 $\mathrm{KA}$ の中でも，その影響を強く受けている関東平野中央部と，その影響の少ない周辺部， 特に太平洋岸とは応力状態が異なる可能性がある。しかし，今のところ，それを区別するだけ の分解能はない.

b) 三浦一房総中部応力区 (MB) について

Fig. 3 (b) はフィリピン海プレートの北西進がこの応力区の $S_{H \max }$ 方位を支配しているこ とを示す概念図である.

$S_{H \text { max }}$ 方位は $1882 / 1902$ 年以来現在までの水平歪の最大短縮軸方位 [北西-南東; 中根・藤 井 (1982) の図 2-1 参照] と良く一致する. しかしながら, 関東地震後現在まで約 50 年間の 測地測量による水平歪の最大短縮軸方位 [注ぼ南-北; 中根・藤井 (1982) の図 5-1 参照] とは 

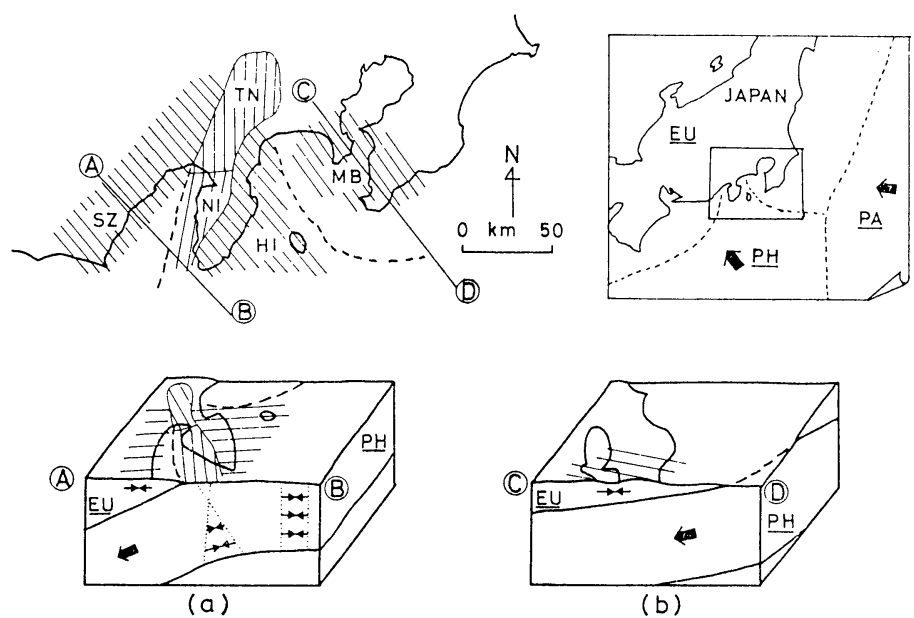

Fig. 3. Illustrations of a model. Parallel lines indicate azimuths of $S_{H \max }$ (see Fig. 2). Large arrows indicate the relative movements of the Philippine Sea plate $(\mathrm{PH})$ and the Pacific plate (PA) with respect to the Eurasian plate (EU). Small arrows in the cross sections represent the direction and relative magnitude of the stresses.

一致しない，藤井・中根 (1982) は，長期のテクトニックな歪の最大短縮軸方位を，関東地震 後に蓄積された歪に重きを置いて，南一北と解釈しているが，より長期の地殼歪で考えると最 大の短縮軸方位は前述のように北西一南東であり，ここで得られた $S_{H \max }$ 方位と良く一致する こと, また Fig. $3(\mathrm{~b})$ に示されるようにこの地域の地下数十 km にあるフィりピン海プレー トの進行方向も北西であることを考え合わせると，この地域の長期のテクトニックな最大短縮 方位は，北西-南東と理解した方が良いだろう，以下のように差応力值の比較においてもこの 推定が支持される.すなわち，1882/1902 年以来の歪によって生ずる差応力 $\left(S_{H \text { max }}-S_{H \text { min }}\right)$ は, 1.7 MPa 程度であるが*, 実測された差応力**と比べてまだ小さく, 1882/1902 年以前か ら長期にわたって北西-南東の圧縮歪が進行していた結果であると考兄られるからである [*歪 をすべて弾性変形と仮定して以下の数值から計算：短縮歪 (北西-南東) $5 \times 10^{-5}$ ・伸び歪（北 東一南西） $-5 \times 10^{-5}$ ，ヤング率 $1.6 \times 10^{4} \mathrm{MPa}$ (千葉県富津市の測定孔中の岩石; 池田・高橋, 1981), ポアソン比 0.2.**例えば富津の深さ $400 \mathrm{~m}$ での測定值は $5 \mathrm{MPa}$; 池田・高橋, 1981].

ところで，MB において現存する応力の $S_{H \max }$ 方位が，北西-南東であるのに対して，関東 地震以後現在までの最大短縮方位がこれと一致していないことは, 現在の差応力の蓄積は大变 効率が悪いことを示している. 差応力が減少している可能性さえある. 現在, 房総半島下では 浅い微小地震が大変少なくほとんど発生していないことは良く知られている. 差応力が，現在 進行中の地殼变動によっては増加しにくい, あるいは増加していないという推定と良く調和す る.

なお，この応力区には関東地震のデータも含をれている. 関東地震は, 地震波の初動から得 られる震央（破壊発生点）は応力区 TN の東端近くに位置するが，地震断層は相模トラフ沿 いに伸びているので [例えば, MATSU'URA et al. (1980)]，この断層の上端辺の中央部の位置 
で表わした方が妥当と思われる（付録の Fig. A-1 中の E 2) からである.

c) 丹沢応力区 $(\mathrm{TN})$ について

この応力区は特異な応力状態を示している.この地域は, フィリピン海プレートが沈み込ま ずに, ニーラシアプレートと衝突している [例宇ば, 杉村 (1972); 石橋 (1980)] と考えられて おり，それから推定される $S_{H \text { max }}$ の方位は北西一南東である. しかし，それとは明らかに異っ て打り,プレートの相互作用を考える上で, 地理的にも重要な位置を占めていることから，そ の原因を明らかにすることは今後の重要な課題である．また，東伊豆応力区 (HI) との境界で の $S_{H \text { max }}$ 方位の変化が，かなりシャープであるように見える点も，この応力区の成因を考え る上で無視できない点であろら.

d) 西伊豆応力区 (NI) について

この応力区も特異な $S_{H \max }$ 応力方位を持っている. Fig. 3 (a) は応力区 NI の成因を説明 するための概念図である.フィリピン海プレート PH が駿河トラフ付近で沈み込み, 曲がる ために，地表近くでは引張力がトラフに垂直方向に加算されるため $S_{H \text { max }}$ 方位はトラフに平 行になる. その結果応力区 HI とは異なった応力方位を持った応力区 NI が出現することにな る.このように, 特異な応力方位を示す区域が, プレートの下方への折れ曲がりのために, プ レートの沈み込み付近で地表近くに生ずることを指摘したのは中村 $(1979,1980)$ である. 中村 は伊豆半島拈よびその周辺の活断層・発震機構・単成火山配列のデータから， $S_{H \max }$ 方位は富 士山付近を中心として，南東側へ放射状に配向していると解釈した．駿河・相模両トラフでの 沈み込みに伴ってフィリピン海プレートが下方へ曲がり， $S_{H \text { max }}$ が放射状になると説明した. しかし，今回の新しいデータをまとめた図からは，応力方位は，放射状よりは，むしろ中野・ 他 (1980) 拉よび小林 (1980) が解釈したように, 伊豆半島を東西に分ける二つの応力区が存在 すると考光た方がデータに忠実のように見える.

そこで，このような伊豆半島中部の， $S_{H \max }$ 方位の急変を説明するモデルについて以下に考

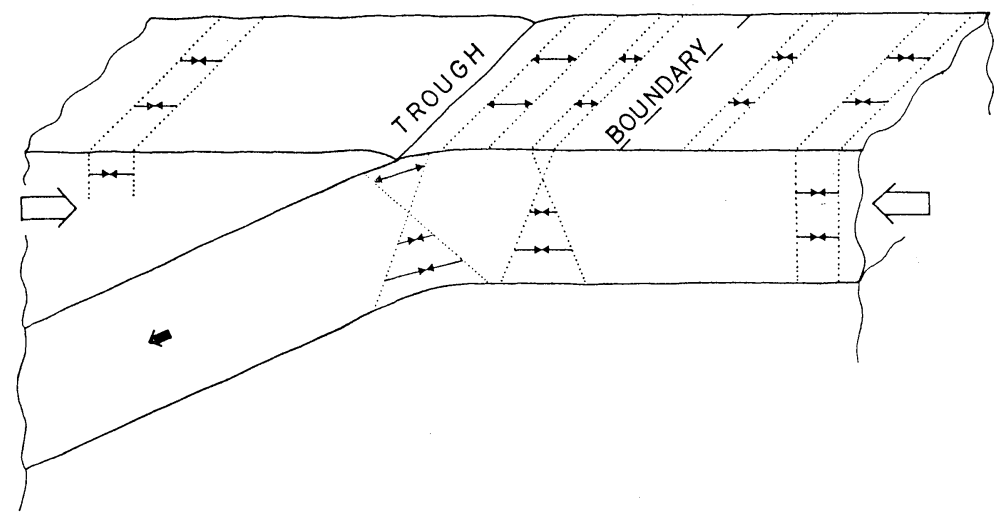

Fig. 4. Schematic drawing of a cross section of a bending plate. Large white arrows indicate the direction of the contraction between two plates. A large black arrow represents the relative movement of a subducting plate. Small arrows indicate the direction of either minimum (outward directed) or maximum (inward directed) compression and relative magnitude. BOUNDARY: Stress province boundary. 
えてみる. Fig. 4 は, プレートの下方への折れ曲がりによって, 地表での $S_{H \text { max }}$ 方位が変化 している様子を示している断面図である．Fig. 4 において，向き合った小さな矢印で示され る圧縮力は，右から左に BOUNDARY に近づくにしたがって，曲げの影響を受けて地表で は小さくなる.一方，トラフと平行な応力成分（図には描か机ていない）はほとんど变化しな いので, BOUNDARY のところで $S_{H \max }$ 方位は，プレートの進む方向からトラフに平行な方 向に入れ替わる. BOUNDARY とトラフ（駿河トラフを想定している）とは平行である. 原 理的には，BOUNDARY で $S_{H \max }$ 方位は突然変化する．しかし一方，相模トラフでの沈み 込みの影響はどうだろらか。相模トラフの北端部の走向と，フィリピン海プレートの北西進と はほぼ同方位なので, 北西進によって伊豆半島東岸付近の，沈み込みによる下方への曲率が増 大することは大変少ない，その影響力が伊豆半島までおよぶことはないだろら。

なお，応力方位は応力区 $\mathrm{TN}$ と良く似ているが，TN が横ずれ断層型および逆断層型であ るのに対して，ここは正断層型および横ずれ断層型である。さらに，フィリピン海プレートの 沈み込みが駿河湾奥以南で進行していると一般に考えられていることを考え合わせて，TN は別の応力区とした。

e) 東伊豆応力区 (HI) について

三浦一房総中部応力区 $(\mathrm{MB})$ と良く似ているが，応力区 $\mathrm{MB}$ と $\mathrm{HI}$ の間をうめるデータが ないこと，間に活動中と考えられる構造線（相模トラフ）があることを考慮して，MB と HI とは別の応力区とした．応力区 HI は横ずれ断層型の応力状態に支配されている．この応力状 態を出現させるためには，フィリピン海プレートの北西進による北西一南東の圧縮力だけでな く, それと直交する方向, 北東一南西の引張力が必要である. その原動力も考える必要がある. 中村 $(1979,1980)$ は駿河トラフと同じく相模トラフでも, その下方への曲がりによって引張 力が生じているためとした。しかし，前述のよらに，トラフの走向と北西進とがほぼ平行して いるので，その効果はそれほど大きくなく，伊豆半島まではおよびにくいと考えられる．相模 トラフからユーラシアプレートの下に既に沈み込んでいるフィリピン海プレートが，自重で最 大傾斜方向である北東方向へ引張り込んでいるのかもしれない.

f) 静岡応力区 (SZ) について

この応力区は, ニーラシアプレートに属しているが, 北西進してくるフィリピン海プレート の影響を受け，北西一南東の $S_{H \text { max }}$ 方位となっていると解䣋される.

\section{§5. ま と め}

(i) 関東・東海地域で得られている応力方位に関するすべてのデータをまとめて，この地域 の最大水平圧縮応力方位分布を得た．使用したデータは，水圧破壊法による測定結果 10 個・ 応力解放法による測定結果 3 個・第四紀の岩脈方位によるもの 7 個・第四紀の単成火山の配列 によるもの 9 個・活断層（確実度 II 以上, 活動度 B 級以上のもの) からの推定 41 個・発震 機構（深度 $<20 \mathrm{~km}, M>6.5 ）$ にるもの 7 個で合計 77 個である.

(ii）隣り合った近くのデータは，測定法および時代の違いによらずおおむね同じ方位，およ び断層の型で分類される同じ応力状態を示しているフフィリピン海プレートが，相模・駿河両 トラフで関東・東海地域の下へ沈み込んでいるというプレートモデルを考慮しつつ，似た方位 のものおよび同じ応力状態のものをまとめて区域分けした７個の区域（応力区）に分けられ 


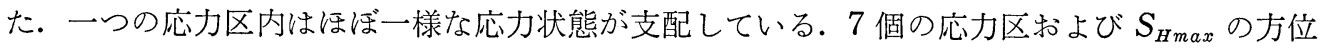
は, 長野県南部 (NA): $\mathrm{N} 85^{\circ} \mathrm{W}$, 関東北部 $(\mathrm{KA}): \mathrm{N} 80^{\circ} \mathrm{W}$, 三浦一房総中部 $(\mathrm{MB}): \mathrm{N} 35^{\circ} \mathrm{W}$, 東伊豆 $(\mathrm{HI}): \mathrm{N} 40^{\circ} \mathrm{W}$, 丹沢 $(\mathrm{TN}): \mathrm{N}-\mathrm{S}$, 西伊豆 $(\mathrm{NI}): \mathrm{N} 10^{\circ} \mathrm{E}$, 静岡 $(\mathrm{SZ}): \mathrm{N} 40^{\circ} \mathrm{W}$ であ る.

このように応力区に分けられた応力分布図は，従来の応力軌跡図 [松田・他 (1978)] とは趣 を異にしている，応力軌跡図が描かれる背景には, “主応力軸方位はなめらかに变化し分布す る”といら考学がある. しかし，均質な物質であっても力の加わり方によって，ある狭い境界 を挾んで $S_{H \max }$ 軸が 90 度変化すること㳊起こりらる点は注意を要する.

(iii) 長野県南部 (NA)・関東北部 (KA) 応力区は， $S_{H \text { max }}$ 方位はほぼ東一西である.これは 太平洋プレートの西進によるものであろう。しかし，データの数はまだ少なく，特に KA に おいてはこの地域の地下深部にもぐり込んでいるフィリピン海プレートの北西進の動きの地表 への影響の北限はどこか, については今のところ定かでなく，今後の課題である.

(iv) 三浦一房総中部応力区 (MB) では $S_{H \max }$ の方位は北西-南東である. これは, この地 域の地下深部で北西進しているフィリピン海プレートの動きの地表への現われが原因であると 推定される. 現存する $S_{H \text { max }}$ 方位と, 現在進行中の地殼変動最大短縮方位 (関東地震後の測 地測量により検出される変動）とが，方位が異なっているためにこの地殼変動による差応力の 増加は大变効率が悪い（あるいは増加していない）と考えられ，このことは房総半島での浅い 微小地震が大変少ないことと良い調和を示している.

(v) 東伊豆 $(\mathrm{HI})$ ・西伊豆 $(\mathrm{NI})$ ・静岡 $(\mathrm{SZ})$ 応力区の間で, 応力状態に関して特徵的なこと が見られる.すなわち， HI と SZ では $S_{H \max }$ の方位はフィリピン海プレートの北西進を反 映して北西一南東であるが，この両地域に挾まれた NI は，北北東一南南西であり，駿河トラフ に泳济平行していることである.これは，フィリピン海プレートの駿河トラフでの下方への曲 がり現象で説明でき，駿河トラフでのフィリピン海プレートのもぐり込みが現在活動的である ことを支持するデータであるともいえる.

（vi）丹沢応力区 (TN) 付近は，フィリピン海プレートのもぐり込み量は大変小さいか，ほ とんどもぐり达んでいないと考えられており[例究ば石橋 (1980)]，そのことから予想される $S_{H \text { max }}$ 方位は，北西一南東である．乙かし $\mathrm{TN}$ の $S_{H \text { max }}$ の方位は注ぼ南北であり，大きな違 いがある，その理由は現在のところ明らかではない。この応力区と HI との境界がかなりシャ ープであることも注目される.

\section{謝辞}

原稿を読んで有益な助言をして下さった筑波大学小林洋二氏に感謝する.

\section{文献}

藤井陽一郎・中根勝見，1982，関東・東海地方の地殼水平変動 (VIII) 一一定常的地殼歪について一， 測地学会誌, 28, 220-229.

HubberT, M.K. and D.G. Willis, 1957, Mechanics of Hydraulic Fracturing, Petroleum Trans. AIME, 210, 153-168.

池田隆司・高橋 博, 1981，千葉県富津市に抢汀る水圧破壊法による地殸応力測定，地震 2, 34, 565576. 


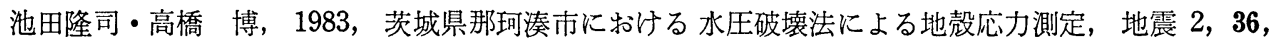
213-223.

石橋克彦, 1976 , 東海地方に予想される大地震の再検討一一駿河湾大地震について一地震学会予稿 集, $2,30-34$.

石橋克彦, 1980, 伊豆半島をめぐる現在のテクトニクス, 月刊地球, 2, 110-119.

IsHIBASHI, K., 1981, Specification of a Soon-to-occur Seismic Faulting in the Tokai District, Central Japan, Based upon Seismotectonics, in Earthquake Prediction-An International Review, Maurice Ewing Series 4, Am. Geophys. Union, pp. 297-332.

JAEGER, J.C. and N.G.W. Cook, 1976, Fundamentals of Rock Mechanics, 2nd ed., John Willey \& Sons, pp. 585.

笠原敬司, 1980, 関東地方の地震発生様式について, 地震学会予稿集 2,66 ; 以下の文献参照: 大竹政 和，1980，防㷋科学技術，41，1-7. および，国立防琰科学技術センター，1981，地震予知連会報， 25, 51-58.

笠原敬司, 1981, 直下型地震とプレートテクトニクス, セキュリティ， 21，13-17.

活断層研究会, 1980, 日本の活断層——分布図々資料, 東大出版会, pp. 363.

小林洋二, 1980, “Tectonic Stress Province” の存在について, 月刊地球, 2, 569-572.

小出 化, 1980, 地震予知のための応力測定の問題点, 月刊地球, $2,578-585$.

小出 仁・星野一男・楠瀬勤一郎・井波和夫・西松裕一 ・ 小泉昇三・秋山政雄， 1981，伊豆下田地区 に打数る応力解放法による地殼応力測定, 地震学会予稿集, 2,20 .

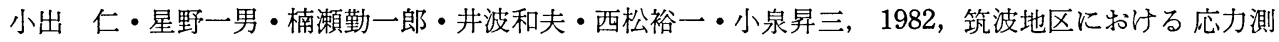
定, 地震学会予稿集, 2,208 .

松田時彦, 1967, 地震の地質学, 地震 $2,20,230-235$.

松田時彦・中村一明・杉村 新, 1978, 活断層とネオテクトニクス, 岩波講座地球科学, 10, 89-157. MCGARR, A. and N.C. GAY, 1978, State of Stress in the Earth's Crust, Ann. Rev. Earth Planet. Sci., 6, 405-436.

MatSu'URA, M., T. IwASAKI, Y. SUzUKI and R. Sato, 1980, Statical and Dinamical Study on Faulting Mechanism of the 1923 Kanto Earthquake, J. Phys. Earth, 28, 119-143.

中村一明, 1969, 広域応力場を反映した火山体の構造, 火山 2, 14, 8-20.

中村一明, 1975, 火山の構造および噴火之地震の関係, 火山 2, 20, 229-240.

Nakamura, K., 1977, Volcanoes as Possible Indicators of Tectonic Stress OrientationPrinciple and Proposal, J. Volcanol. Geotherm. Res., 2, 1-16.

NaKamura, K., K.H. JACOB and J.N. Davies, 1977, Volcanoes as Possible Indicators of Tectonic Stress Orientation-Aleutians and Alaska, Pure Appl. Geophys., 115, 87-112.

中村一明, 1979, 駿河トラフ東方の主応力線——゚レートの曲り, 地震 2, 32, 370-372.

中村一明, 1980, 伊豆のテクトニクスとプレートの曲り, 月刊地球, 2, 94-102.

中根勝見・藤井陽一郎, 1982, 関東・東海地方における地殸水平変動 (VII) 一一算出された地殼歪の 状況一一, 測地学会誌, 28, 152-161.

中野佳昭・杉田 理・井口博夫・小林洋二， 1980，岩脈群から見た伊豆半島のテクトニクス，月刊地 球, 2, 103-109.

ODE, H., 1975, Mechanical Analysis of the Dike Pattern of the Spanish Peaks Area, Colorado, Bull. Geol. Soc. Amer., 68, 567-576.

杉村 新, 1972, 日本付近におけるプレートの境界, 科学, 42, 192-202.

塚原弘昭・池田隆司・佐竹 洋・大竹政和・高橋 博, 1978, 静岡県岡部町に抢ける水圧破壊法に上 る地殼応力の測定, 地震 $2,31,415-433$.

塚原弘昭・池田隆司・佐竹 洋・高橋 博, 1980 , 静岡県西伊豆町における水圧破壊法による地殼応 力測定, 地震 $2,33,317-327$.

塚原弘昭・池田隆司・佐竹 洋・高橋 博, 1981 , 銚子市犬吠埼における水圧破壊法による地殼応力 湘定, 地震 $2,34,13-20$.

塚原弘昭・池田隆司・高橋 博, 1983a, 水圧破壊法に上る地殼応力測定一一静岡県岡部町, 修善寺町, 下田市，神奈川県横須賀市での測定，地震 $2,36,551-569$.

塚原弘昭・池田隆司・高橋 博，1983b，水圧破壊法による地殼応力測定一一山梨県都留市および茨城 県筑波での測定，地震学会予稿集，2, 107. 
ZOBACK, M.L. and M.D. ZoBACK, 1980, State of Stress in the Conterminous United States, J. Geophys. Res., 85, 6113-6156.

\section{付録引用文献}

1）塚原弘昭・池田隆司 - 高橋 博, 1983, 地震 2, 36, 551-569

2) 塚原弘昭 - 池田隆司 - 佐竹 洋 - 高橋 博, 1980 , 地震 $2, \mathbf{3 3}, 317$.

3）池田隆司・高橋 博, 1981 , 地震 $2,34,565$.

4) 未発表（塚原弘昭・池田隆司・佐竹 洋・高橋 博，1981，地震 $2,34,13$ の原データの見直しに よる).

5）池田隆司 - 高橋 博, 1983, 地震 2, 36, 213.

6) 小出 仁, 1980 , 月刊地球, 2,578 .

7) 小出 化・他 7 名, 1981 , 地震学会予稿集, 2,20

8）小出 化・他 5 名, 1982, 地震学会予稿集, $2,208$.

9) ABE, K., 1974, J. Geophys. Res., 79, 4393.

10) Matsu'URa, M., T. IWASAKI, Y. Suzuki and R. Sato, 1980, J. Phys. Earth, 28, 119.

11) 阿部勝征, 1977, 地震学会予稿集, $1,82$.

12) 井元政二郎・他 4 名, 1981, 地震 2, 34, 481.

13）気象庁地震課・石廊崎測候所・大島測候所，1978，験震時報， $43 ， 21$.

14）牧 正, 1974, 震研速報, 14, 23.

15) 活断層研究会, 1980, 東大出版会, pp. 363.

16) Research Group for Active Faults of Japan, 1980, J. National Disaster Sci., 2, 61.

17）河内晋平, 1974 , 蓼科山地域の地質 (5 万分の 1 図幅), 地質調査所; 河内晋平, 1977 , 八ガ岳地 域の地質 (5 万分の 1 図幅), 地質調査所.

18） 津屋弘迬, 1943, 震研查報, 21, 376 .

19) 中村一明, 1969, 火山 $2,14,8$.

20) 小林洋二, 1982, 談話.

21) 小川, 1977; 中村一明, 1980, 月刊地球, 2,94 .

22) 久野 久, 1937, 地理評論, 13，836; 中村一明, 1980, 月刊地球, 2, 94.

23）荒牧重雄・葉室和親, 1977, 震研彙報, 52, 235.

24）江川竜一郎， 1974，東海大海洋資源卒論; 中野佳昭・杉田 理・井口博夫・小林洋二, 1980 , 月 刊地球, 2, 103 .

25）中野佳昭・杉田 理 - 井口博夫 - 小林洋二, 1980, 月刊地球, $2,103$.

26) Kuno, H., 1964, Bull. Volcanol., 27, 53.

27) 白尾元理, 1981, 地質雑, 87, 641 .

28) Nakamura, K., 1961, Sci. Pap. Coll. Gen. Educ. Univ. Tokyo, 11, 281; 中村一明, 1969, 火山 $2,14,8$.

29）塚原弘昭 - 池田隆司 - 高橋 博, 1983, 地震学会予稿集, 2, 107. 


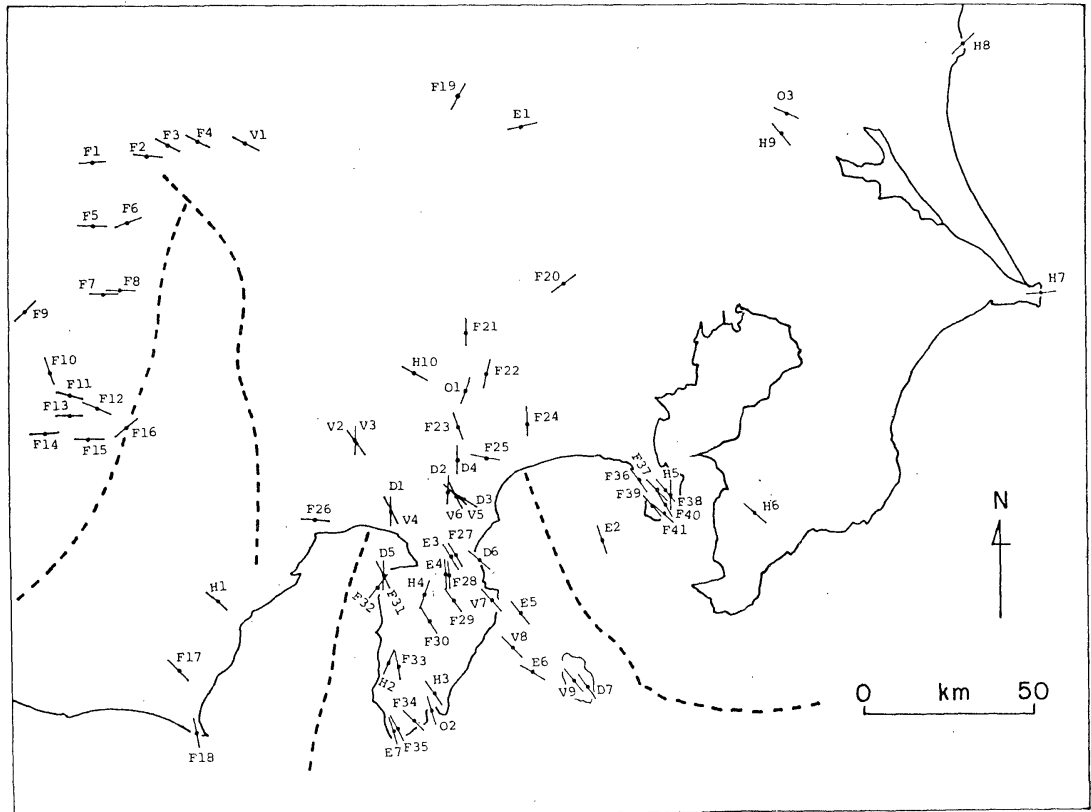

Fig. A-1. Index map for data points and $S_{\text {Hmax }}$ directions.

Appendix: List of stress orientation data

Table A-1. In-situ stress mesurements.

\begin{tabular}{|c|c|c|c|c|c|c|}
\hline Site & $\begin{array}{c}S_{H \max } \\
\text { azimuth }\end{array}$ & Location & $\begin{array}{l}\text { Depth } \\
(\mathrm{m})\end{array}$ & $\begin{array}{l}\text { Stress } \\
\text { condition } \\
\text { at depth* }\end{array}$ & $\begin{array}{c}\text { Stress } \\
\text { orientation } \\
\text { data }\end{array}$ & Ref. \\
\hline \multicolumn{7}{|c|}{ Hydraulic Fracturing Method } \\
\hline H 1 & $\mathrm{~N} 50^{\circ} \mathrm{W}$ & Okabe & $220-420$ & $\mathrm{~T}$ & 4 & $(1)$ \\
\hline $\mathrm{H} 2$ & $\mathrm{~N} 20^{\circ} \mathrm{E}$ & Nishiizu & $260-440$ & $\mathrm{~S}$ or $\mathrm{N}$ & 3 & ( 2$)$ \\
\hline $\mathrm{H} 3$ & $\mathrm{~N} 35^{\circ} \mathrm{W}$ & Shimoda & $70-440$ & $\mathrm{~S}$ & 3 & $(1)$ \\
\hline $\mathrm{H} 4$ & $\mathrm{~N} 20^{\circ} \mathrm{E}$ & Shuzenji & $140-330$ & $\mathrm{~S}$ & 2 & ( 1$)$ \\
\hline $\mathrm{H} 5$ & $\mathrm{~N} 5^{\circ} \mathrm{W}$ & Yokosuka & 190 & $\mathrm{~S}$ or $\mathrm{N}$ & 1 & ( 1$)$ \\
\hline $\mathrm{H} 6$ & $\mathrm{~N} 50^{\circ} \mathrm{W}$ & Futtsu & $210-290$ & $\mathrm{~T}$ or $\mathrm{S}$ & 3 & ( 3 ) \\
\hline $\mathrm{H} 7$ & $\mathrm{~N} 85^{\circ} \mathrm{E}$ & Choshi & 100 & $\mathrm{~T}$ & 1 & ( 4$)$ \\
\hline H 8 & $\mathrm{~N} 45^{\circ} \mathrm{E}$ & Nakaminato & $220-350$ & $\mathrm{~T}$ & 4 & ( 5$)$ \\
\hline H 9 & $\mathrm{~N} 45^{\circ} \mathrm{W}$ & Tsukuba & 560 & $\mathrm{~T}$ & 1 & (29) \\
\hline $\mathrm{H} 10$ & $\mathrm{~N} 60^{\circ} \mathrm{W}$ & Tsuru & $80-390$ & $\mathrm{~T}$ & 3 & (29) \\
\hline \multicolumn{7}{|c|}{ Overcoring method } \\
\hline O 1 & $\mathrm{~N} 20^{\circ} \mathrm{E}$ & Tanzawa & $5-10$ & $\mathrm{~T}$ & 3 & ( 6$)$ \\
\hline O 2 & $\mathrm{~N} 20^{\circ} \mathrm{W}$ & Shimoda & $15-20$ & $\mathrm{~T}$ & 3 & ( 7 ) \\
\hline O 3 & $\mathrm{~N} 67^{\circ} \mathrm{W}$ & Tsukuba & 16 & $\mathrm{~S}$ & 1 & ( 8 ) \\
\hline
\end{tabular}

*: Estimated from linear extrapolation of the stress gradient data to the depth, $\mathrm{T}$ : Reverse fault type stress condition, N: Normal fault type and S: Strike-slip fault type. 
Table A-2. Volcano structure: Dike trends.

\begin{tabular}{cclccc}
\hline \hline Site & $\begin{array}{c}S_{\text {Hmax }} \\
\text { azimuth }\end{array}$ & \multicolumn{1}{c}{ Location } & $\begin{array}{c}\text { Number } \\
\text { of dikes }\end{array}$ & $\begin{array}{c}\text { Age } \\
\text { (Ma) }\end{array}$ & Ref. \\
\hline D1 & $\mathrm{N}-\mathrm{S}$ & Ashitakayama & 24 & 1 & $(24)$ \\
$\mathrm{D} 2$ & $\mathrm{~N}-\mathrm{S}$ & Hakone, northern part (Kintokisan) & 4 & 0.3 & $(25)$ \\
$\mathrm{D} 3$ & $\mathrm{~N} 55^{\circ} \mathrm{W}$ & Hakone, southern part & 96 & 0.3 & $(26)$ \\
$\mathrm{D} 4$ & $\mathrm{~N}-\mathrm{S}$ & Yaguradake & 23 & 2 & $(25)$ \\
D5 & $\mathrm{N}-\mathrm{S}$ & Osezaki (Darumayama) & 4 & 0.3 & $(27)$ \\
$\mathrm{D} 6$ & $\mathrm{~N} 50^{\circ} \mathrm{W}$ & Ajiro & 5 & 2 & $(25)$ \\
$\mathrm{D} 7$ & $\mathrm{~N} 35^{\circ} \mathrm{W}$ & Mihara (Izuoshima) & 7 & 0.01 & $(28)$ \\
\hline
\end{tabular}

Table A-3. Volcano structure: Monogenetic volcano alignments (including flank volcanoes).

\begin{tabular}{cclccc}
\hline Site & $\begin{array}{c}S_{\text {Hmax }} \\
\text { azimuth }\end{array}$ & Volcano & $\begin{array}{c}\text { Number } \\
\text { of vents }\end{array}$ & $\begin{array}{c}\text { Age } \\
\text { (Ma) }\end{array}$ & Ref. \\
\hline V1 & $\mathrm{N} 65^{\circ} \mathrm{W}$ & Kita-yatsugatake & 6 & 0.2 & $(17)$ \\
V2 & $\mathrm{N} 35^{\circ} \mathrm{W}$ & Fuji & 80 & 0.01 & $(18)(19)$ \\
V3 & $\mathrm{N}-\mathrm{S}$ & Fuji & 80 & 0.01 & $(18)(20)$ \\
V4 & $\mathrm{N} 25^{\circ} \mathrm{W}$ & Ashitakayama & - & 0.1 & $(21)$ \\
V5 & $\mathrm{N} 50^{\circ} \mathrm{W}$ & Hakone, on old caldera rim & 8 & 0.2 & $(22)$ \\
V6 & $\mathrm{N} 25^{\circ} \mathrm{W}$ & Hakone, in caldera & 7 & 0.05 & $(22)$ \\
V7 & $\mathrm{N} 40^{\circ} \mathrm{W}$ & Higashiizu (Ohmuroyama) & 40 & 0.04 & $(23)$ \\
V8 & $\mathrm{N} 45^{\circ} \mathrm{W}$ & Izu-higashioki* & 40 & $(0.04)$ & $(23)$ \\
V9 & $\mathrm{N} 40^{\circ} \mathrm{W}$ & Mihara (Izuoshima) & 50 & 0.01 & $(19)$ \\
\hline
\end{tabular}

*: Monogenetic volcano group.

Table A-4. Fault movement: Active faults (Ref. 15)

\begin{tabular}{|c|c|c|c|c|c|c|c|}
\hline Site & $\begin{array}{l}S_{H \max } \\
\text { azimuth }\end{array}$ & Fault & $\begin{array}{l}\text { Hault } \\
\text { type }\end{array}$ & Strike & Certainty & Activity & $\begin{array}{l}\text { Age } \\
\text { (Ma) }\end{array}$ \\
\hline F 1 & $\mathrm{~N} 85^{\circ} \mathrm{E}$ & Mutoyama & $\mathrm{R}$ & $\mathrm{N} 55^{\circ} \mathrm{E}$ & $\mathrm{I}$ & $A-B$ & - \\
\hline F 2 & $\mathrm{~N} 85^{\circ} \mathrm{W}$ & Takaosan & $\mathrm{R}$ & $\mathrm{N} 65^{\circ} \mathrm{E}$ & II & B & - \\
\hline F 3 & $\mathrm{~N} 65^{\circ} \mathrm{W}$ & Shimosuwa & $\mathrm{N}$ & $\mathrm{N} 65^{\circ} \mathrm{W}$ & I & $\mathrm{B}$ & 0.04 \\
\hline F 4 & $\mathrm{~N} 65^{\circ} \mathrm{W}$ & Kirigamine & $\mathrm{R}$ & $\mathrm{N} 85^{\circ} \mathrm{E}$ & I & $\mathrm{A}$ & 0.12 \\
\hline F 5 & $\mathrm{E}-\mathrm{W}$ & Kamiya & $\mathrm{L}$ & $\mathrm{N} 60^{\circ} \mathrm{W}$ & I & $\mathrm{A}$ & 0.03 \\
\hline F 6 & $\mathrm{~N} 70^{\circ} \mathrm{E}$ & Ogurogawa & $\mathrm{R}$ & $\mathrm{N} 40^{\circ} \mathrm{E}$ & I & A & 0.0005 \\
\hline F 7 & $\mathrm{E}-\mathrm{W}$ & Sanshukaido & $\mathrm{T}$ & $\mathrm{N}-\mathrm{S}$ & I & $\mathrm{B}$ & 0.02 \\
\hline F 8 & $\mathrm{E}-\mathrm{W}$ & Tagiri & $\mathrm{T}$ & $\mathrm{N}-\mathrm{S}$ & I & $\mathrm{B}$ & 0.02 \\
\hline F 9 & $\mathrm{~N} 45^{\circ} \mathrm{E}$ & Seinaijitoge & $\mathrm{R}$ & $\mathrm{N} 15^{\circ} \mathrm{E}$ & I & $\mathrm{B}$ & - \\
\hline F 10 & $\mathrm{~N} 20^{\circ} \mathrm{W}$ & Iida-Matsukawa & $\mathrm{R}$ & $\mathrm{N} 50^{\circ} \mathrm{W}$ & II & $\mathrm{B}$ & - \\
\hline F 11 & $\mathrm{~N} 75^{\circ} \mathrm{W}$ & Kawaji-Tatsuoka & $\mathrm{T}$ & $\mathrm{N} 15^{\circ} \mathrm{E}$ & I & $\mathrm{B}$ & - \\
\hline F 12 & $\mathrm{~N} 65^{\circ} \mathrm{W}$ & Shimoinaryuto & $\mathrm{T}$ & $\mathrm{N} 25^{\circ} \mathrm{E}$ & II & $\mathrm{B}$ & - \\
\hline F 13 & $E-W$ & Shimoinaryusei & $\mathrm{T}$ & $\mathrm{N}-\mathrm{S}$ & I & $\mathrm{B}$ & - \\
\hline $\mathrm{F} 14$ & $\mathrm{~N} 85^{\circ} \mathrm{E}$ & Suzugasawa & $\mathrm{L}$ & $\mathrm{N} 65^{\circ} \mathrm{W}$ & I & $\mathrm{B}$ & - \\
\hline F 15 & $\mathrm{E}-\mathrm{W}$ & Hiraoka & $\mathrm{R}$ & $\mathrm{N} 60^{\circ} \mathrm{E}$ & I & $\mathrm{B}-\mathrm{C}$ & - \\
\hline F 16 & $\mathrm{~N} 50^{\circ} \mathrm{E}$ & Meadian Tectonic Line & $\mathrm{R}$ & $\mathrm{N} 20^{\circ} \mathrm{E}$ & I & A & - \\
\hline $\mathrm{F} 17$ & $\mathrm{~N} 45^{\circ} \mathrm{W}$ & Niohtsujihigashi & $\mathrm{N}$ & $\mathrm{N} 45^{\circ} \mathrm{W}$ & I & $B-C$ & 0.1 \\
\hline F 18 & $\mathrm{~N} 10^{\circ} \mathrm{E}$ & Hirosawa & $\mathrm{L}$ & $\mathrm{N} 20^{\circ} \mathrm{E}$ & I & $\mathrm{B}-\mathrm{C}$ & 0.08 \\
\hline F 19 & $\mathrm{~N} 30^{\circ} \mathrm{E}$ & Hirai & $\mathrm{T}$ & $\mathrm{N} 60^{\circ} \mathrm{W}$ & I & B & 0.02 \\
\hline
\end{tabular}


Table A-4. (continued)

\begin{tabular}{|c|c|c|c|c|c|c|c|}
\hline Site & $\begin{array}{c}S_{H \max } \\
\text { Azimuth }\end{array}$ & Fault & $\begin{array}{l}\text { Hault } \\
\text { type }\end{array}$ & Strike & Certainty & Activity & $\begin{array}{l}\text { Age } \\
\text { (Ma) }\end{array}$ \\
\hline $\mathrm{F} 20$ & $\mathrm{~N} 55^{\circ} \mathrm{E}$ & Tachikawa & $\mathrm{T}$ & $\mathrm{N} 35^{\circ} \mathrm{W}$ & I & B & 0.02 \\
\hline F 21 & $\mathrm{~N}-\mathrm{S}$ & Oogiyama & $\mathrm{T}$ & $E-W$ & II & $\mathrm{B}-\mathrm{C}$ & - \\
\hline F 22 & $\mathrm{~N} 15^{\circ} \mathrm{E}$ & Chojagoya & $\mathrm{L}$ & $\mathrm{N} 45^{\circ} \mathrm{E}$ & $\mathrm{I}$ & B & - \\
\hline F 23 & $\mathrm{~N} 20^{\circ} \mathrm{W}$ & Kannawa & $\mathrm{T}$ & $\mathrm{N} 70^{\circ} \mathrm{E}$ & I & A & 0.08 \\
\hline F 24 & $\mathrm{~N}-\mathrm{S}$ & Hatano & $\mathrm{T}$ & $\mathrm{E}-\mathrm{W}$ & I & B & 0.12 \\
\hline F 25 & $\mathrm{~N} 80^{\circ} \mathrm{W}$ & Jizohdo-Yuhinotaki & $\mathrm{N}$ & $\mathrm{N} 80^{\circ} \mathrm{W}$ & II & B & 0.5 \\
\hline $\mathrm{F} 26$ & $\mathrm{~N} 85^{\circ} \mathrm{W}$ & Iriyama & $\mathrm{T}$ & $\mathrm{N} 5^{\circ} \mathrm{E}$ & I & B & - \\
\hline F 27 & $\mathrm{~N} 30^{\circ} \mathrm{W}$ & Tanna & $\mathrm{L}$ & $\mathrm{N}-\mathrm{S}$ & I & A & 0 \\
\hline F 28 & $\mathrm{~N} 5^{\circ} \mathrm{W}$ & Ohno & $\mathrm{L}$ & $\mathrm{N} 25^{\circ} \mathrm{E}$ & I & B & - \\
\hline F 29 & $\mathrm{~N} 35^{\circ} \mathrm{W}$ & Himenoyu & $\mathrm{R}$ & $\mathrm{N} 65^{\circ} \mathrm{W}$ & I & B & - \\
\hline F 30 & $\mathrm{~N} 30^{\circ} \mathrm{W}$ & Mizunuki-Yoichizaka & $\mathrm{R}$ & $\mathrm{N} 60^{\circ} \mathrm{W}$ & I & B & - \\
\hline F 31 & $\mathrm{~N} 25^{\circ} \mathrm{W}$ & Kinkazanhigahi & $\mathrm{L}$ & $\mathrm{N} 5^{\circ} \mathrm{E}$ & I & B & - \\
\hline F 32 & $\mathrm{~N} 35^{\circ} \mathrm{E}$ & Funayama & $\mathrm{N}$ & $\mathrm{N} 35^{\circ} \mathrm{E}$ & I & B & - \\
\hline F 33 & $\mathrm{~N} 10^{\circ} \mathrm{W}$ & Kadono & $\mathrm{L}$ & $\mathrm{N} 20^{\circ} \mathrm{E}$ & I & B & - \\
\hline F 34 & $\mathrm{~N} 45^{\circ} \mathrm{W}$ & Kamikamo & $\mathrm{R}$ & $\mathrm{N} 75^{\circ} \mathrm{W}$ & II & $\mathrm{B}-\mathrm{C}$ & - \\
\hline F 35 & $\mathrm{~N} 25^{\circ} \mathrm{W}$ & Irozaki & $\mathrm{R}$ & $\mathrm{N} 55^{\circ} \mathrm{W}$ & I & B & 0 \\
\hline F 36 & $\mathrm{~N} 35^{\circ} \mathrm{W}$ & Takeyamaseibu & $\mathrm{R}$ & $\mathrm{N} 65^{\circ} \mathrm{W}$ & I & A & 0.08 \\
\hline F 37 & $\mathrm{~N} 45^{\circ} \mathrm{W}$ & Kitatakeminami & $\mathrm{R}$ & $\mathrm{N} 75^{\circ} \mathrm{W}$ & II & A & 0.1 \\
\hline F 38 & $\mathrm{~N} 40^{\circ} \mathrm{W}$ & Kitatake & $\mathrm{R}$ & $\mathrm{N} 70^{\circ} \mathrm{W}$ & I & A & 0.006 \\
\hline F 39 & $\mathrm{~N} 40^{\circ} \mathrm{W}$ & Minamishimoura & $\mathrm{R}$ & $\mathrm{N} 70^{\circ} \mathrm{W}$ & I & B & 0.006 \\
\hline $\mathrm{F} 40$ & $\mathrm{~N} 30^{\circ} \mathrm{W}$ & Takeyamatohbu & $\mathrm{R}$ & $\mathrm{N} 60^{\circ} \mathrm{W}$ & II & A & 0.006 \\
\hline F 41 & $\mathrm{~N} 50^{\circ} \mathrm{W}$ & Hikihashi & $\mathrm{R}$ & $\mathrm{N} 80^{\circ} \mathrm{W}$ & I & B & 0.006 \\
\hline
\end{tabular}

For the strike-slip faults, $S_{H \max }$ azimuths are derived from $30^{\circ}$ declination from the strike direction. Fault Type R: Right-lateral strike-slip, L: Left-lateral strike-slip, T: Reverse, and $\mathrm{N}$ : Normal faults. Certainty ranking I: "It is certain from conclusive evidence that the fault was active during the Quaternary", and II: "It is not definitely certain that the fault was active during the Quaternary, yet it is possible to infer the sense of the displacement" (after Ref. 16). Degree of fault activity A: Average slip rate $>1 \mathrm{~m} / 1000$ years, B: $1 \mathrm{~m} / 1000$ years > Average slip rate $\geqq 0.1 \mathrm{~m} / 1000$ years, and C: $0.1 \mathrm{~m} / 1000$ years $>$ Average slip rate $\geqq 0.01 \mathrm{~m} / 1000$ years (after Ref. 16). Age: Age of the youngest bed in the formations cut by the fault.

Table A-5. Fault movement: Focal mechanisms of earthquakes $(M>6.5$, depth $<20 \mathrm{~km})$.

\begin{tabular}{cllccccc}
\hline \hline Site & $\begin{array}{c}S_{\text {Hmax }} \\
\text { azimuth }\end{array}$ & Earthquake (year) & $\begin{array}{c}\text { Magni- } \\
\text { tude }\end{array}$ & $\begin{array}{c}\text { Fault } \\
\text { type }\end{array}$ & Strike* & $\begin{array}{c}\text { Depth } \\
(\mathrm{km})\end{array}$ & Ref. \\
\hline $\mathrm{E} 1$ & $\mathrm{~N} 76^{\circ} \mathrm{E}$ & Nishisaitama $(1931)$ & 7.0 & $\mathrm{~L}$ & $\mathrm{R} 74^{\circ} \mathrm{W}$ & 1 & $(9)$ \\
$\mathrm{E} 2$ & $\mathrm{~N} 20^{\circ} \mathrm{W}$ & Kanto (1923) & 7.9 & $\mathrm{R}-\mathrm{T}$ & $\mathrm{N} 66^{\circ} \mathrm{W}$ & 14 & $(10)^{* *}$ \\
$\mathrm{E} 3$ & $\mathrm{~N} 30^{\circ} \mathrm{W}$ & Kitaizu, northern part $(1930)$ & 7.0 & $\mathrm{~L}$ & $\mathrm{~N}-\mathrm{S}$ & 0 & $(11)$ \\
$\mathrm{E} 4$ & $\mathrm{~N} 3^{\circ} \mathrm{W}$ & Kitaizu, southern part $(1930)$ & 7.0 & $\mathrm{~L}$ & $\mathrm{~N} 27^{\circ} \mathrm{E}$ & 0 & $(11)$ \\
$\mathrm{E} 5$ & $\mathrm{~N} 39^{\circ} \mathrm{W}$ & Izuhanto-tohooki $(1980)$ & 6.7 & $\mathrm{~L}$ & $\mathrm{~N} 9^{\circ} \mathrm{W}$ & 18 & $(12)$ \\
$\mathrm{E} 6$ & $\mathrm{~N} 60^{\circ} \mathrm{W}$ & Izuoshima-kinkai $(1978)$ & 7.0 & $\mathrm{R}$ & $\mathrm{E}-\mathrm{W}$ & 0 & $(13)$ \\
$\mathrm{E} 7$ & $\mathrm{~N} 9^{\circ} \mathrm{W}$ & Izuhanto-oki (1974) & 6.9 & $\mathrm{R}$ & $\mathrm{N} 39^{\circ} \mathrm{W}$ & 0 & $(14)$ \\
\hline
\end{tabular}

*: One of two nodal planes, which agrees with the after-shock alignment.

**: Result calculated based on geodetic data. 